\title{
New Approach for Isolation of Individual Caseins from Cow Milk by the Preparative Electrophoresis
}

\author{
Andrii V. Iukalo \\ Ternopil Ivan Pul'ui National Technical University, Ternopil, Ukraine \\ Email: biotech@tu.edu.te.ua \\ Received 25 July 2014; revised 11 November 2014; accepted 26 September 2014 \\ Copyright (C) 2014 by author and Scientific Research Publishing Inc. \\ This work is licensed under the Creative Commons Attribution International License (CC BY). \\ http://creativecommons.org/licenses/by/4.0/

(c) (i) Open Access

\begin{abstract}
This paper carried out a comparative analysis of different types of electrophoretic systems which were used for the analysis of casein complex from cow milk (polyacrylamide gel electrophoresis: for the neutral and acidic native conditions, in gradient variant, the presence of sodium dodecyl sulphate or with including urea). Taking into attention the separation efficiency, complexity of electrophoretic system, the impact of system components, we have selected the anode system of the homogeneous gel in the presence of urea as the basis for the preparation of casein fractions. It also changed the composition and the structure of the electrophoretic apparatus. The changes allow purification of casein fractions up to several grams during one stage of treatment (for 5 hours). The purified casein fractions were tested for the homogeneity and have been recommended for using in the biomedical researches, including the processes of the formation of the bioactive peptides.
\end{abstract}

\section{Keywords}

Casein, Isolation, Individual Forms, Electrophoresis, Preparative

\section{Introduction}

To date, progress has been made in the study of the structure and physicochemical properties of caseins, namely, it found their fractional composition, determined primary structure. There is some progress in establishing the spatial structure of these proteins, formation of micelles and it proposed models that allow reflecting the biochemical conversion of caseins from their synthesis to splitting during the digestive processes in the gastrointestinal tract of mammalians [1]. However, in recent works it was found that in addition to basic functions-protein 
nutrition, casein can affect on the physiological functions of various body systems of mammalians. Such regulation may be realized on the level of some products of the limited proteolysis of caseins during the normal digestion at the influence of the enzymes of the gastrointestinal tract. It established casein peptides that can affect on the cardiovascular (antithrombotic and antihypertensive), nervous (agonists and antagonists of opioid receptors), immune (immune modulator and antimicrobial peptides) and digestive systems [2] [3]. It also established that bioactive peptides can be formed from casein protein in dairy products by the action of proteolytic enzymes of lactic acid bacteria and milk coagulate drugs. These results led to the further development and expansion of ideas about the biological significance of protein in the diet, including natural dietary proteins - caseins, which some authors call pro-hormones of dietary hormones - formones (from food hormones) [4].

Since biologically active peptides of varying types may be formed from various fractions of casein complex, the very important question is the selection and purification casein fractions. Up to date, there are quite bulky and long term laboratory methods for the purification of the individual caseins, which often include the action of extreme factors that lead to the destruction of the native structure of molecules [5]. Regarding the purification of casein fractions in an industrial scale, the needed methods have not been developed, and casein fractions are not produced. There are only a few publications concerning preparations of the individual casein fractions (namely: fraction of $\beta$-CN-5P) in case of the production of women milk substrates, and the regulation of the physicochemical properties of the casein solutions [6]. In this regard, relevant is the development of methods for the isolation and purification of casein precursor of natural bioactive peptides that can be used to study the biochemical processes of formation of these structures in vitro and accepted as a basis for industrial scale. Obtaining casein fractions is complicated by the similarity of their properties and family values of molecular weights [1]. In this regard, attractiveness is the use of electrophoresis approach. There are many different options electrophoresis systems used for the analysis of fractional caseins [7] [8]. Also it should be noted that the differences in electrophoresis mobility is the basis of modern classification caseins [9].

Given the above, the purposes of our work are the selection of effective electrophoresis system and create on its basis preparative technique for one step process of the isolation of the individual casein fractions.

\section{Materials and Methods}

The total casein was isolated from fresh skimmed milk with the simultaneous inactivation of natural milk proteinases [10]. Homogeneous fractions $\alpha_{\mathrm{S} 1}-\mathrm{CN}$ and $\beta$-CN were received by the differential precipitation at the isoelectric point in the presence of urea and then to-purification by the ion-exchange chromatography on the columns of DEAE-cellulose (DEAE-52, "Serva", Germany), as it was previously described in [10]. Homogeneous fraction $\alpha_{\mathrm{S} 2}-\mathrm{CN}$ was isolated from the total casein by the ion-exchange chromatography. Conditions of the ion-exchange chromatography were similar to those described previously in [11]. Homogeneous $\kappa-\mathrm{CN}$ was isolated by the gel-filtration chromatography on columns $(2 \times 70 \mathrm{~cm})$ for the liquid chromatography from company "Renal” (Hungary) filled with Sephadex G-150 ("Pharmacia”, Sweden). The conditions of the gel filtration described in [12].

The concentration of protein was determined by the method of Lowry, or by spectrophotometer (SF-46, $\lambda$-280 $\mathrm{nm}$ ). It was used a previously installed absorption coefficients for different fractions of casein (D $1 \%$ in $1 \mathrm{~cm}$ ): 10.0 - for $\alpha_{\mathrm{S} 1}-\mathrm{CN}$; 4.6-for $\beta$-CN; 9.6-for $\kappa$-CN; 10.1-for $\alpha_{\mathrm{S} 2}-\mathrm{CN}$ and 8.2 for total casein.

Fractional composition of total casein and the homogeneity of its fractions at different stages of the isolation were analyzed by the electrophoresis on the vertical plates of the polyacrylamide gel (PAGE) [7]. At this it was used an alkaline buffer system containing $25 \mathrm{mM}$ of Tris, $27 \mathrm{mM}$ of dietylbarbiturate, $3 \mathrm{mM}$ of ethylenediaminetetraacetate (EDTA) and $4.5 \mathrm{M}$ of urea. Electrophoregram's were fixed and stained by conventional methods. Electrophoretic buffers and gels prepared using reagents company "Reanal" (Hungary) and "Sigma" (USA). Also, specific reagents domestic productions (chemical and high purification) were used. Quantitative estimation of electrophoregrams were performed by constructing densitograms, using readable graphics way, as described in [13].

In addition to these general methods the total casein was fractionated by other types of electrophoresis: disc electrophoresis in native conditions, as acidic and neutral proteins [7], in the presence of sodium dodecyl sulfate [7], and in gradient gels [14]. Plates of electrophoresis were carried out in the apparatus type Studier. Apparatus, electrophoretic chamber and formers were made in our laboratory. For electrophoresis in gel columns it was used machine from company "Reanal” (Hungary). 


\section{Results and Discussion}

At the first stage, we have conducted a comparative study of different anodic electrophoretic polyacrylamide gel systems, which were previously used for the analysis of total casein and its fractions [7] [10] [14]. At the first step it was chosen two types of disc-electrophoresis (in native conditions, in the presence of sodium dodecyl sulfate (SDS), gradient and homogeneous separating gels) and with homogeneous PAGE electrophoresis in the presence of urea.

The results of disc electrophoresis with SDS and disc electrophoresis in gradient PAGE showed that these systems are not effective for the separation of the total casein. In both cases, the main fraction of caseins $\left(\alpha_{\mathrm{S} 1}-\mathrm{CN}, \beta-\mathrm{CN}\right)$ are very close and almost merge on electrophoregrams. This complicates their identification and separation. The reason for this is probably close values of molecular weights $\left(\alpha_{\mathrm{S} 1}-\mathrm{CN} \_23614\right.$ and $\beta$-CN-23974) and abnormally high binding casein by SDS (SDS more than $1.4 \mathrm{mg}$ at $1 \mathrm{mg}$ protein). The number of bound $\mathrm{SDS}$ in $\alpha_{\mathrm{S} 1}-\mathrm{CN}$ and $\kappa$-CN increases with increasing temperature and in case of $\beta$-CN its level decreases. Typical electrophoregram of the most effective separation of caseins is shown in Figure 1 . The results indicate that the system disk electrophoresis in native conditions allow to separate and identify the major fraction of caseins $\left(\alpha_{\mathrm{S} 1}-\mathrm{CN}\right.$ and $\beta$-CN). Identification of $\alpha_{\mathrm{S} 2}-\mathrm{CN}$ and $\kappa-\mathrm{CN}$ is complicated due to their formation of supramolecular structures in such conditions. For this reason, there is possible to loss fractions $\alpha_{\mathrm{S} 1}-\mathrm{CN}$ and $\beta$-CN. The identification of the numerous minor fractions was not possible.

The most suitable for the identification and separation of caseins is anode homogeneous system in the presence of urea in PAGE (Figure 1, Figure 2). From the electrophoregrams it can see that all casein fractions, according to the current international classification [9], are in descending order of their electrophoretic mobility. This electrophoretic system was chosen by us as a basis for developing methods of the preparative electrophoresis of casein. To achieve this goal it was necessary to simplify the electrophoretic system, reduce time of the duration of the procedure fulfilment and, more importantly, increasing the amount of casein, which can be divided into fractions. In this regard, we have excluded $\beta$-mercaptoethanol and reduced the concentration of urea that did not significantly effect on the quality of the separation of the major casein fractions. Reducing the duration of electrophoresis was reached by decreasing the concentration of PAGE and through more early process finishing on a relatively control zone of leader dye. The increasing the amount of casein in the sample was made through the modification of cameras, formers of PAGE and increasing the protein concentration. As a result, the duration of electrophoresis was reduced in 1.5 times at the overall time of procedure fulfilment about 50 min and almost 100 times increasing the amount of protein in the sample without noticeable performance degradation division major casein fractions. Detailed results of the preparative electrophoresis of casein are shown in Figure 2.

It is shown that $\alpha_{\mathrm{S} 2}$-CN caseins form one united faction opposed to analytical variation, where $\alpha_{\mathrm{S} 2}$-CN caseins presented in the form of four factions $\left(\alpha_{\mathrm{S} 2}-\mathrm{CN}-13 \mathrm{P}, \alpha_{\mathrm{S} 2}-\mathrm{CN}-12 \mathrm{P}, \alpha_{\mathrm{S} 2}-\mathrm{CN}-11 \mathrm{P}\right.$ and $\left.\alpha_{\mathrm{S} 2}-\mathrm{CN}-10 \mathrm{P}\right)$. Also $\kappa$-casein form one electrophoretic fraction. In general, with the resulting PAGE plate it is possible to distinguish a major caseins groups that differ in primary structure ( $\alpha_{\mathrm{S} 1}-\mathrm{CN}, \alpha_{\mathrm{S} 2}-\mathrm{CN}, \beta-\mathrm{CN}$ and $\left.\kappa-\mathrm{CN}\right)$.

To identify fractions of casein we conducted a rapid color stripes then they were isolated from PAGE through the cutting the gel band containing the appropriate fraction. In control experiments it was found that at the time of the staining and the identification the area of the individual fractions of caseins did not expand and mix in the gel. In next experiments it was established the time needed for the extraction of individual fractions from the gel in a buffer solution, which in its composition corresponded to 2-fold diluted buffer for gel electrophoretic system. Figure 3 shows the output of the individual casein fractions in the solution with the relevant parts of PAGE. The graph shows the average value of three measurements. For $\kappa$-CN and $\alpha_{\mathrm{S}_{2}}$-CN extraction can stop after 120 min, and for $\alpha_{\mathrm{S} 1}-\mathrm{CN}$ and $\beta$-CN-after $150 \mathrm{~min}$.

The obtained fractions after extraction were analyzed for their electrophoretic homogeneity (Figure 4). On the electrophoregrams it is shown homogeneous fractions $\alpha_{\mathrm{S} 1}-\mathrm{CN}$ and $\beta$-CN. Factions $\kappa-\mathrm{CN}$ and $\alpha_{\mathrm{S} 2}-\mathrm{CN}$ is more blurred, because each of them consisting of several components.

To underline the efficiency of the proposed approach we given some its characteristics in the comparison of the number of others traditional used methods for the preparative fractioning casein (Table 1). The main attention was paid such characteristics as: time of fractioning, quantitative yield of product, intensity of purification of fractions, cost of the needed reagents and equipment's. As it can see from the presented data the proposed approach for the preparative electrophoresis provides more high level of homogeneity of casein fractions, demands small time for its accomplishing and is less expensive. 


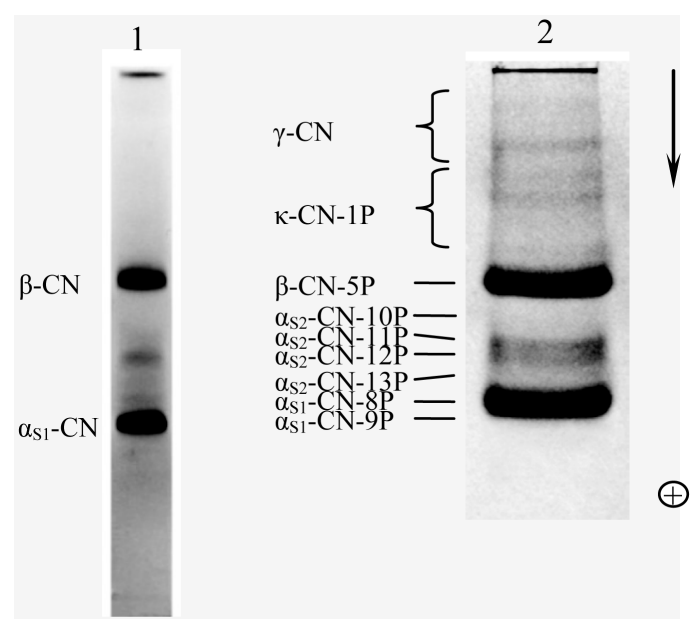

Figure 1. Electrophoregrams of total casein obtained by disc-electrophoresis in native conditions (1) and in homogeneous PAAG in the presence of urea (2).
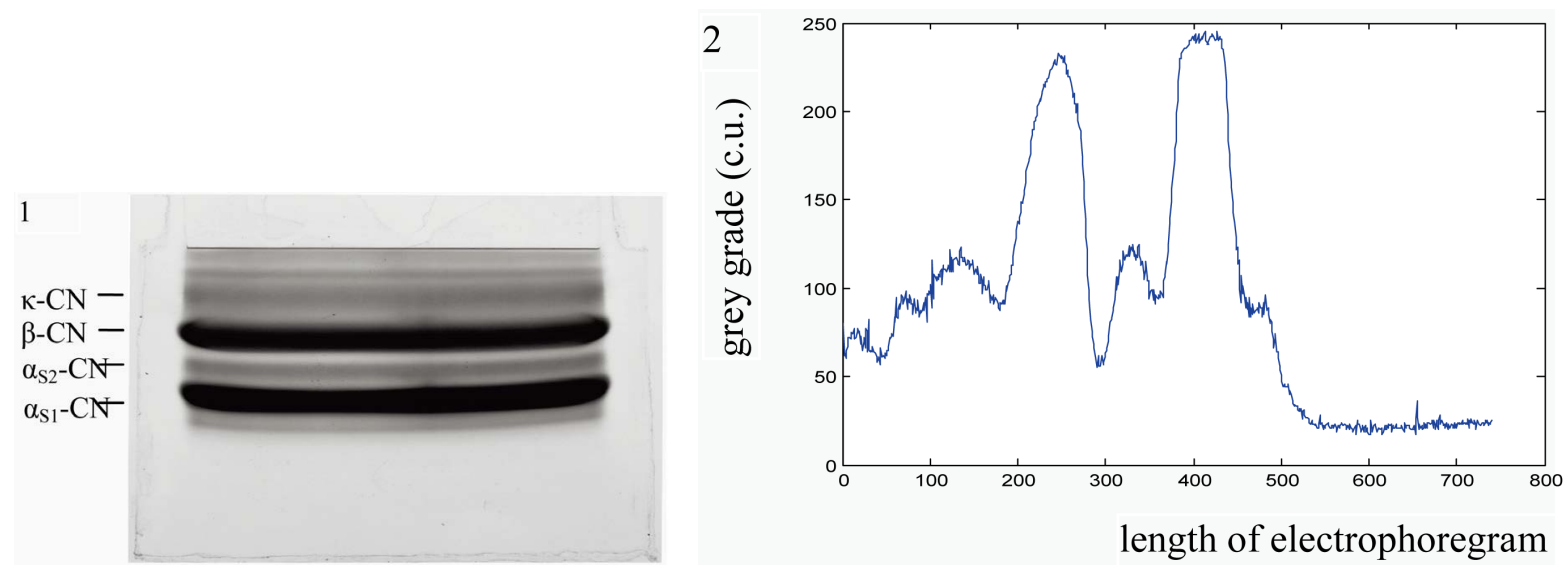

Figure 2. Electrophoregram (1) and its densitogram (2) at the fractionation of the total casein by the preparative variant of the anodic electrophoretic system with the application of homogeny PAAG.

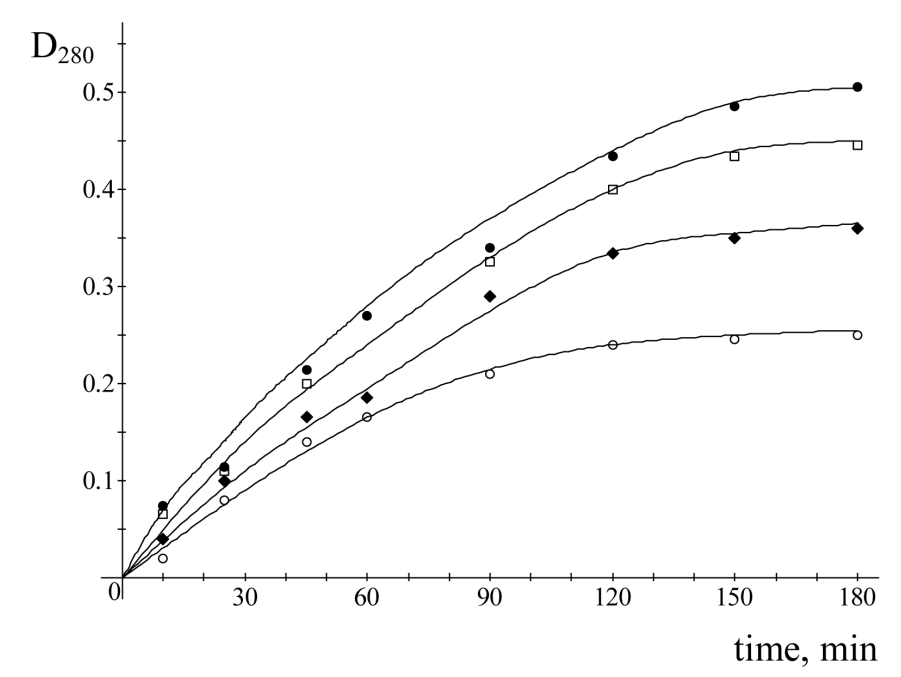

Figure 3. Intensity of extraction of casein fractions from PAAG: $\mathrm{O}$ $-\kappa-\mathrm{CN} ;-\alpha_{\mathrm{S} 2}-\mathrm{CN} ; \square-\beta-\mathrm{CN} ; \bigcirc-\alpha_{\mathrm{S} 1}-\mathrm{CN}$. 


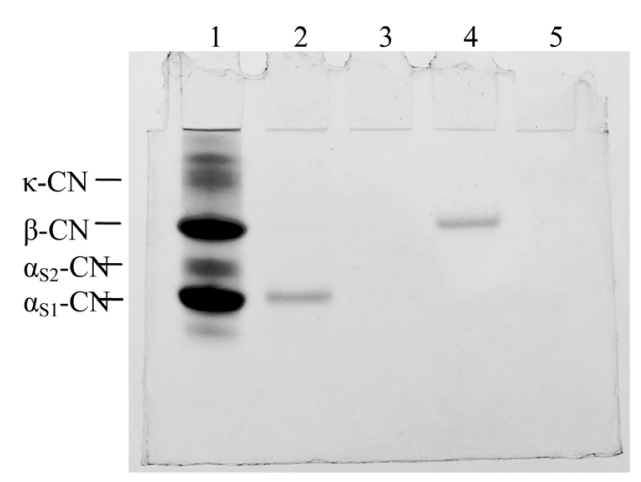

Figure 4. Electrophoregrams of the extracted casein fractions: 1) control sample; 2) $\alpha_{\mathrm{S} 1}-\mathrm{CN}$; 3) $\alpha_{\mathrm{S} 2}-\mathrm{CN}$; 4) $\beta$-CN; 5) $\kappa-\mathrm{CN}$.

Table 1. Comparative characteristics of the different methods used for the preparative isolation of gram quantities of the individual caseins.

\begin{tabular}{|c|c|c|c|c|c|}
\hline Method of fractioning & Caseins & Theoretical yield, \% & Protein, \% & $\begin{array}{c}\text { Time of } \\
\text { fractioning, h }\end{array}$ & Cost (in \$) \\
\hline \multirow[b]{2}{*}{$\begin{array}{l}\text { Gel-filtration on Sephadex } \\
\text { (G-100, G-150) }\end{array}$} & $\kappa$ & $\sim 70$ & $70-77$ & 7 & \multirow[b]{2}{*}{$\begin{array}{l}10000 \text { - } 15000 \\
\text { (dependence on system of } \\
\text { liquid chromatography) }\end{array}$} \\
\hline & $\alpha_{\mathrm{S} 1}$ and $\beta$ & $\begin{array}{l}\text { Repeated } \\
\text { gel filtration } \\
\sim 30-40\end{array}$ & $75-80$ & 14 & \\
\hline \multirow{3}{*}{$\begin{array}{l}\text { Ion-exchanges } \\
\text { chromatography on } \\
\text { DEAE cellulose }\end{array}$} & $\alpha_{\mathrm{S} 1}$ & \multirow{3}{*}{$\sim 70-80$} & $>77$ & \multirow{3}{*}{9} & \multirow{3}{*}{$\begin{array}{l}10000 \text { - } 15000 \\
\text { (dependence on system of } \\
\text { liquid chromatography), }\end{array}$} \\
\hline & $\beta$ & & $>80$ & & \\
\hline & $\kappa$ & & $>75$ & & \\
\hline \multirow{2}{*}{$\begin{array}{l}\text { Differential precipitation } \\
\text { in the presence of urea }\end{array}$} & $\alpha_{\mathrm{S} 1}$ & \multirow[b]{2}{*}{$\sim 40-50$} & $>75$ & \multirow{2}{*}{48} & \multirow{2}{*}{$\begin{array}{l}\qquad 1200 \\
\text { (with additional centrifuge for } \\
\text { very big volumes In } 1 \text { - } 3 \mathrm{~L} \text { ) }\end{array}$} \\
\hline & $\beta$ & & $>80$ & & \\
\hline \multirow{4}{*}{$\begin{array}{c}\text { Preparative } \\
\text { electrophoresis in anode } \\
\text { system of homogenous } \\
\text { PAAG }\end{array}$} & $\alpha_{\mathrm{S} 1}$ & \multirow{4}{*}{$\sim 75-85$} & $>93$ & & \multirow{4}{*}{$\begin{array}{l}1500 \\
\text { (device prepared in laboratory } \\
\text { of author) }\end{array}$} \\
\hline & $\alpha_{\mathrm{S} 2}$ & & $>90$ & & \\
\hline & $\beta$ & & $>95$ & 5 & \\
\hline & $\kappa$ & & $>90$ & & \\
\hline
\end{tabular}

\section{Conclusion}

Thus, using a modified version of anodic electrophoretic system with the uniform PAGE in the presence of urea, there is possibility to obtain in one step of process the electrophoretic pure fractions of caseins. The whole process takes less than five hours. Modification of the device allows for electrophoresis fractionation gram quantities of casein. The device can be easily produced in the laboratory. Comparing with other methods of the selection of caseins (liquid chromatography, differential precipitation, and ultrafiltration) the proposed method is more simple and accessible. Given the characteristics of the structure and properties of caseins, the principle of electrophoresis may be promising for the fractionation of caseins on an industrial scale.

\section{References}

[1] Horne D.S. (2009) Casein Micelle Structure and Stability. In: Thompson, A. and Boland, M., Eds., Milk Proteins: From Expression to Food, Academic Press/Elsevier, Amsterdam, Boston, 133-162.

[2] Hartmann, R. and Meisel, H. (2007) Food-Derived Peptides with Biological Activity: From Research to Food Applications. Current Opinion in Biotechnology, 18, 163-169. http://dx.doi.org/10.1016/j.copbio.2007.01.013

[3] Iukalo, A.V., Storozh, L.A. and Yukalo, V.G. (2012) Cow Milk Casein Complex (Bos Taurus) Proteins as Precursors of Bioactive Peptides. Biotechnology, 5, 21-33.

[4] Gobetti, M., Minervini, F. and Grizzello, C. (2004) Angiotensin I-Converting-Enzyme-Inhibitory and Antimicrobial 
Bioactive Peptides. International Journal of Dairy Technology, 57, 173-188. http://dx.doi.org/10.1111/j.1471-0307.2004.00139.x

[5] Whitney, R. (1999) Proteins of Milk. Fundamentals of Dairy Chemistry. Aspen Publishers, Gaithersburg, 81-169.

[6] Park, Y.W. (2009) Bioactive Components in Milk and Dairy Products. Wiley-Blackwell, Boston, 426 p. http://dx.doi.org/10.1002/9780813821504

[7] Yukalo, A., Yukalo, V. and Shynkaryk, M. (2009) Electrophoretic Separation of the Milk Protein. Proceeding of the International Conference on Bio and Food Electrotechnologies, Compiegne, 22-23 October 2009, 227-231.

[8] Skalka, V.V., Savchuk, O.M. and Ostapchenko, L.I. (2010) Determination of Different Forms of Casein in Milk by Disc-Electrophoresis Method. Physics of Lieve, 18, 36-38.

[9] Farrell Jr., H.M., Jimenez-Flores, R., Bleck, G.T., et al. (2004) Nomenclature of the Proteins of Cows’ Milk-Sixth Revision. Journal of Dairy Science, 87, 1641-1674. http://dx.doi.org/10.3168/jds.S0022-0302(04)73319-6

[10] Yukalo, V. (2005) Obtaining of Casein Protein Complex from Cow Milk. Nutracos, 5, 17-19.

[11] Yukalo, V.G. (2001) Ion-Exchange Chromatography of Proteins of Casein Complex in Volume. Medical Chemistry, 4, 52-56.

[12] Yukalo, V.G. (2001) Gel-Filtration of Proteins of Casein Complex. Medical Chemistry, 2, 35-38.

[13] Yukalo, V.G., Javorskij, B.I., Storozh, L.A. and Solovodzins’ka, I.Y. (2007) Quantitative Electrophoretic Analysis of Casein Complex Proteins. Biology of Animals, 9, 295-298.

[14] Kas'min, S.D. and Sherban, S.D. (1978) Determination of the Molecular Weight of Nuclear Proteins by Method of Disc-Electrophoresis in Gradient of Polyacrylamide Gel. Ukr. Biochem. Zhurn., 50, 108-115. 
Scientific Research Publishing (SCIRP) is one of the largest Open Access journal publishers. It is currently publishing more than 200 open access, online, peer-reviewed journals covering a wide range of academic disciplines. SCIRP serves the worldwide academic communities and contributes to the progress and application of science with its publication.

Other selected journals from SCIRP are listed as below. Submit your manuscript to us via either submit@scirp.org or Online Submission Portal.
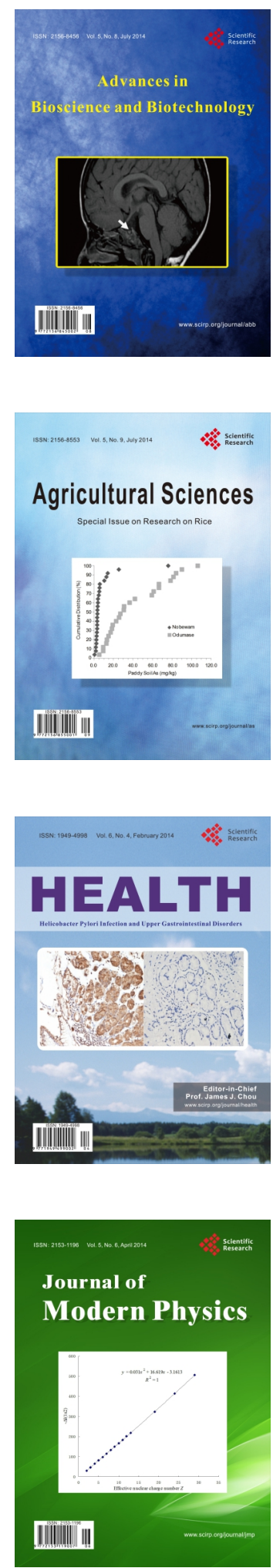
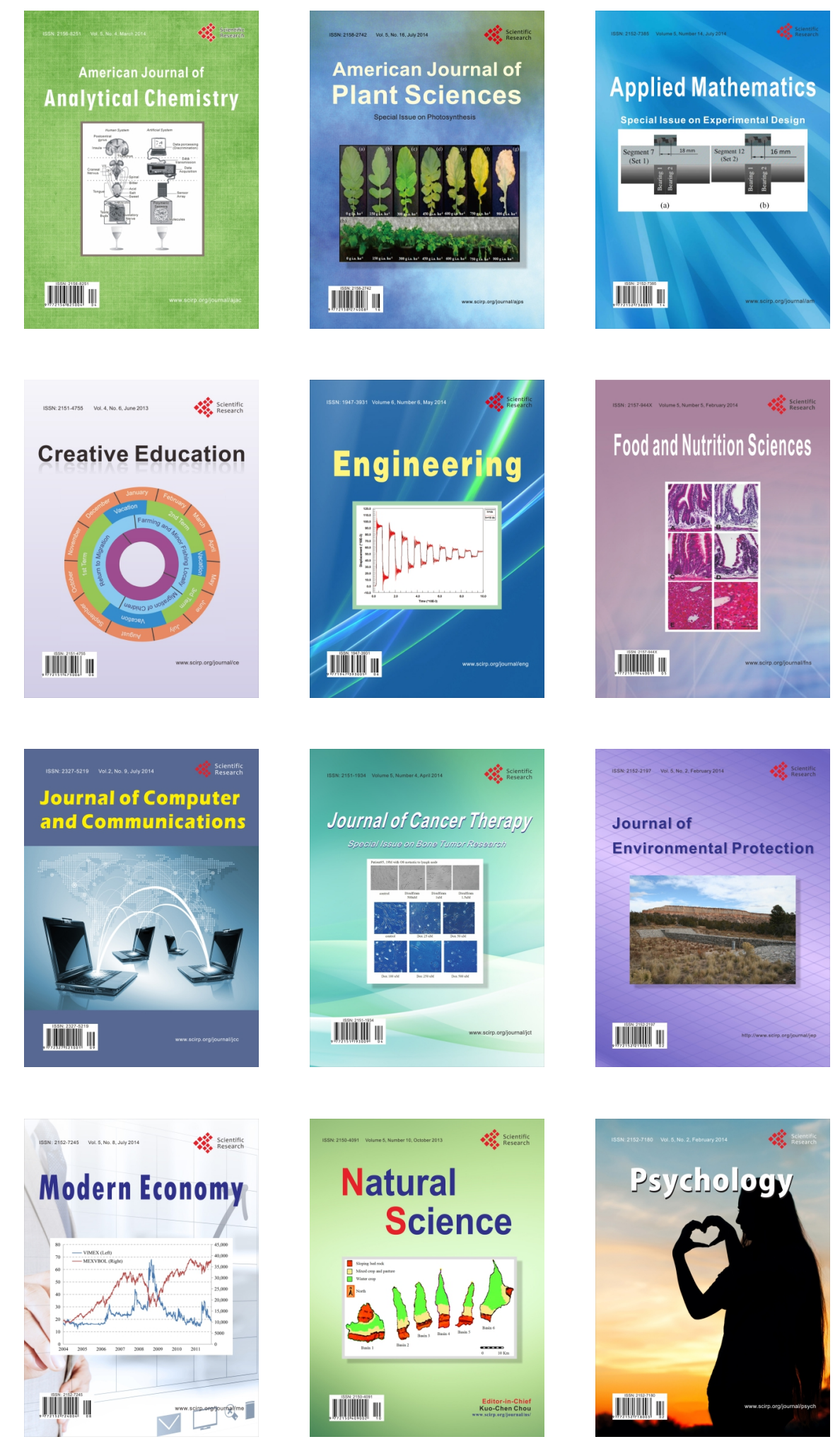